\title{
AIR FLOW IN REPTILIAN VENTILATION
}

\author{
Carl Gans and Brian D. Clark \\ Division of Biological Sciences. The University of Michigan. Ann Arbor.
} MI 48109. U.S.A.

(Received 7 October 1977)

\begin{abstract}
Ventilatory air flow was measured at the nostrils of unrestrained representatives of all major surviving groups of reptiles.

1. Flow is always biphasic (out-in-pause) in resting, undisturbed reptiles.

2. Rib movements do not necessarily reflect flow.

3. Flow may become triphasic (out-in-out-pause) in excited animals.

4. Previous reports of triphasic flow during reptilian ventilation probably reflect misinterpretation of strain gauge records, use of excited animals, and utilization of closed manometric (Kopfkappe) systems (known to induce artifacts).
\end{abstract}

\section{INTRODUCTION}

An extensive series of papers (Mitchell \& Morehouse, 1863; Heinemann, 1877; Dubjuga, 1882; CharbonnelSalle, 1883; Siefert, 1896; Couvreur, 1898; FrançoisFrank, 1909; Babak, 1914; Willem \& Bertrand, 1936; Randall et al., 1944; Servaty \& Peyraud, 1960; Templeton \& Dawson, 1963; Templeton, 1964; Bennett, 1973; Rosenberg, 1973: Gatz et al., 1975: Jammes \& Grimaud, 1976) has supported the idea that reptiles ventilate their lungs triphasically by an outflow inflow-partial outflow pattern (between the variably prolonged apneustic intervals). On the other hand. there have also been many reports (Mitchell \& Morehouse, 1863; Bert, 1869; Rouch, 1886; Kahn, 1902; Vos, 1936; Boelaert, 1941; McCutcheon, 1943; Gans \& Hughes, 1967; Gaunt \& Gans, 1969; Naifeh et al., 1970; Hughes, 1973, 1974; Tenney et al.. 1974; Gans \& Clark, 1976; Wood et al., 1977) supporting the concept that ventilation proceeds biphasically, with an outflow followed by an inflow. The vast majority of such studies used indirect indicators of flow, deriving their conclusions from pressures, pulmonary or thoracic volume, movements of the thorax, impedance of the body, electromyography, and similar measures.

A series of recent studies combining electromyography and pressure recording (Gans \& Hughes, 1967; Gaunt \& Gans, 1969; Jongh \& Gans, 1969; Gans \& Clark, 1976) led to a theoretical review (Gans, 1971) suggesting that (a) the amount of work carried out in pulmonary ventilation is presumably signifcant to the animal, and (b) ventilation ordinarily consists of outflow followed by inflow and is hence strictly biphasic. Stimulated by this apparent conflict in the literature, we obtained a miniature flowmeter and started to measure tidal airflow directly. A first paper (Clark et al., 1978) documents that flow is biphasic in snakes. We report here on direct measurements of airflow patterns in members of all other orders of currently surviving reptiles.

\section{MATERIALS AND METHODS}

Experiments were run at various temperatures, mainly between 24 and $25^{\circ} \mathrm{C}$, on the animals given in Table 1 ,
Table 1. Species used in this study

\begin{tabular}{clcc}
\hline $\begin{array}{c}\text { No. of } \\
\text { specimens }\end{array}$ & \multicolumn{1}{c}{ Species } & Mass & $\begin{array}{c}\text { Parameters } \\
\text { monitored* }\end{array}$ \\
\hline 2 & Sphenodon punctatus & $720 \mathrm{~g}$ & $\mathrm{~F}$ \\
1 & Boa constrictor & $6.0 \mathrm{~kg}$ & $\mathrm{~F} . \mathrm{Pr}, \mathrm{Th}$ \\
2 & Python regius & $1.0 \mathrm{~kg}$ & $\mathrm{~F} . \mathrm{Pr}$. Th \\
1 & Thamnophis sirtalis & $37 \mathrm{~g}$ & $\mathrm{~F}$ \\
1 & Amphisbaena alba & $120 \mathrm{~g}$ & $\mathrm{~F}$ \\
2 & Cordylus sp. & $16 \mathrm{~g}$ & $\mathrm{~F}$ \\
1 & Varanus nehulosus & $1.1 \mathrm{~kg}$ & $\mathrm{~F} . \mathrm{Th}$ \\
1 & Crotaphytus collaris & $37 \mathrm{~g}$ & $\mathrm{~F}$ \\
2 & Sauromalus obesus & $160+180 \mathrm{~g}$ & $\mathrm{~F}, \mathrm{Th}$ \\
1 & Chrysemys scripta & $230 \mathrm{~g}$ & $\mathrm{~F}$ \\
1 & Caiman crocodilus & $2.0 \mathrm{~kg}$ & $\mathrm{~F}$ \\
\hline
\end{tabular}

* $\mathrm{F}=$ air flow at nostril

$\mathrm{Th}=$ diameter of thorax.

$\mathrm{Pr}=$ intratracheal pressure.

which also indicates supplementary manipulations carried out on each individual. In some animals the trachea was intubated with curved non-occlusive catheters. inserted through the tracheal wall as described by Gans \& Clark (1976).

The sensing elements-paired Fenwall GC32L 8 bead thermistors- of a bidirectional flowmeter (Hill \& Givens, 1969) were placed in a tube, the end of which could be positioned over the reptile's nostril by means of individually shaped extensions of polyethylene tubing. This configuration was necessary because the unshielded unit is so sensitive that its reponse to convection currents would otherwise produce a very high noise level. The thermistors are coupled to yield positive and negative deflections from a baseline value, in this case reflecting exhalation and inhalation via the nostrils, respectively. The time-constant of the flowmeter is approximately $0.2 \mathrm{sec}$ (undriven decay from 71 to $26 \%$ of full scale deflection).

Small pieces of velcro plastic were glued onto the skin of the head or back of the animals and matching pieces on the body of the flowmeter. The flowmeter and its extension tubing and cable (with matching pieces of velcro) could then be positioned to cause minimal restriction of the activity of the animal. A mercury strain gauge around the trunk indicated body wall movements. These were monitored in parallel with airflow and occasionally with fluctuations of pressure in the trachea. All leads were long 

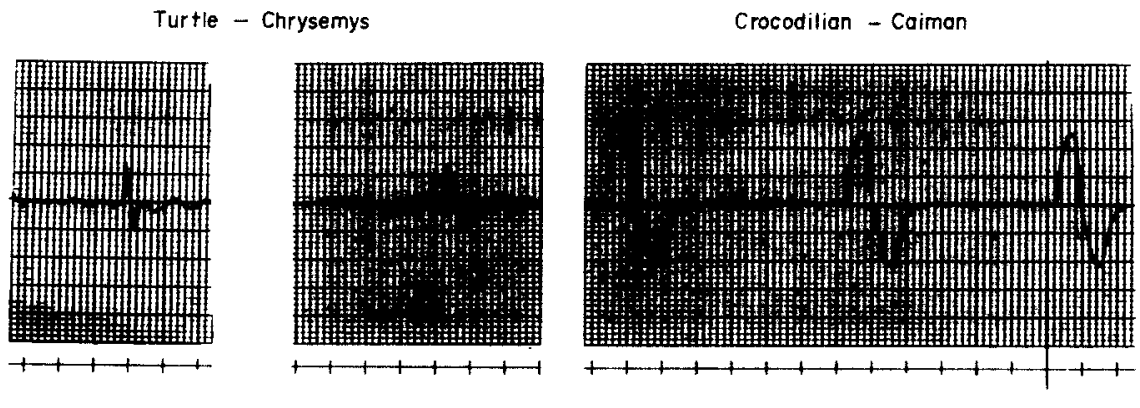

Snoke - Boa

Lizard - Souromalus
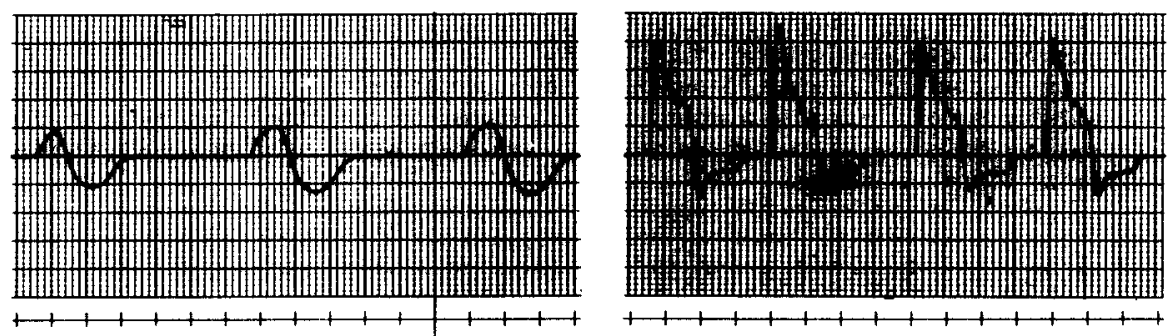

Worm Lizord - Amphisbaena

Tuatara - Spenodon
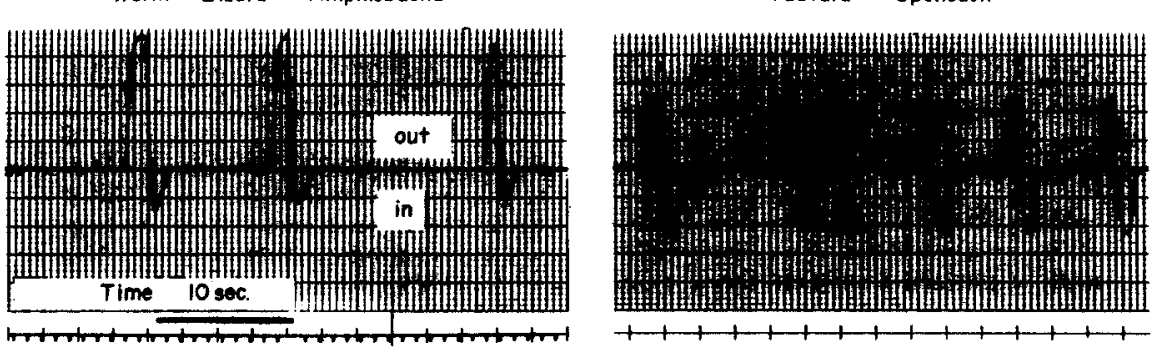

Fig. 1. Records of airflow from the nostrils of resting, undisturbed representatives of the six major groups of surviving reptiles. Airflow is biphasic in every case, although in Chrysemys pulmonary ventilation is interspersed between periods of buccal flushing.

enough to permit free movement of the animals within an enclosure.

\section{RESULTS}

The results are clear and unequivocal. Figures 1-3 show samples of the flow patterns observed. The flow trace always shows an exhalation followed by an inhalation unless the animals are excited, in which case a minor tertiary exhalation is occasionally observed. Movements of the polyethylene sampling tube occasionally produced asymmetry of the inflow and outflow curves, apparently reflecting differential leakage, as the tube generally did not occlude the nasal aperture. Other reasons for asymmetry of responses to inflow and outflow streams are (a) slight shifts of the position of the paired thermistors in the airstream. (b) variable saturation of the gases with moisture, and (c) the tendency for outfiow to be exaggerated because its jet is directed toward the sampling tube. (The latter effect is important as it emphasizes that terminal outflow-the so-called $E_{2}$ phase-would have been recognized if it had indeed occurred.)

The flow readings also correlate excellently with records of intratracheal pressure. There is certainly no indication that the flowmeter readings reflect anything but mechanical events.

The readings obtained from strain gauges reflect rib movements, but are also affected by other factors such as position of the gauge, the way the trunk of the animal is curved, and the depth of ventilation. Figure 2, recorded from a small monitor lizard, illustrates that airflow is not necessarily correlated with rib movement. While airflow is biphasic (out-in), the ribs often move triphasically (in-out-in). Figure 3 illustrates the effect of excitement on the ventilatory pattern, indicating a shift of the strain gauge output at rest (due to inflation of the trunk), a marked increase in the tidal volume, and a slightly secondary exhalation after the inhalation.

\section{DISCUSSION}

The results here reported support the earlier observations that resting reptiles normally use biphasic ventilation. It appears that some of the earliest reports, suggesting that ventilation is triphasic, reflect the nature of the recording apparatus. However, incidental observations during our investigations indicate that more recent authors might consider ventilation 


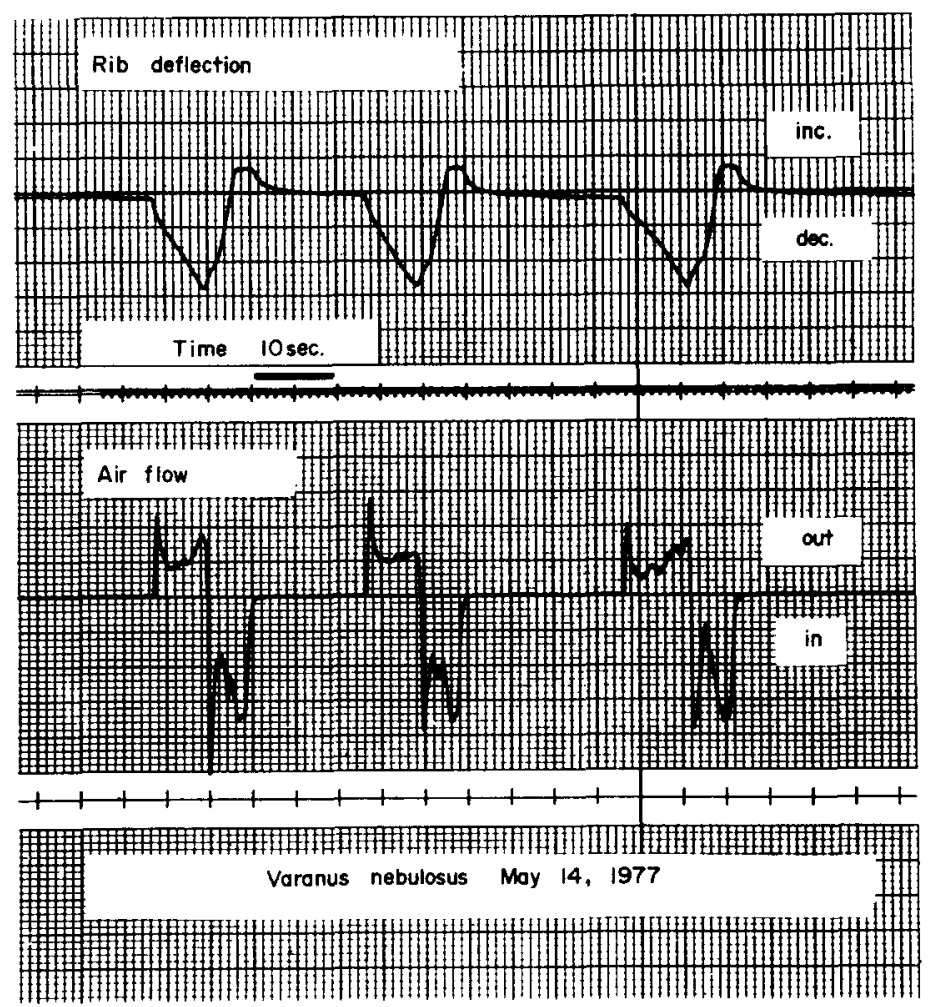

Fig. 2. Simultaneous records of airflow and thoracic diameter in a resting monitor lizard. Airflow is biphasic while movements are triphasic.
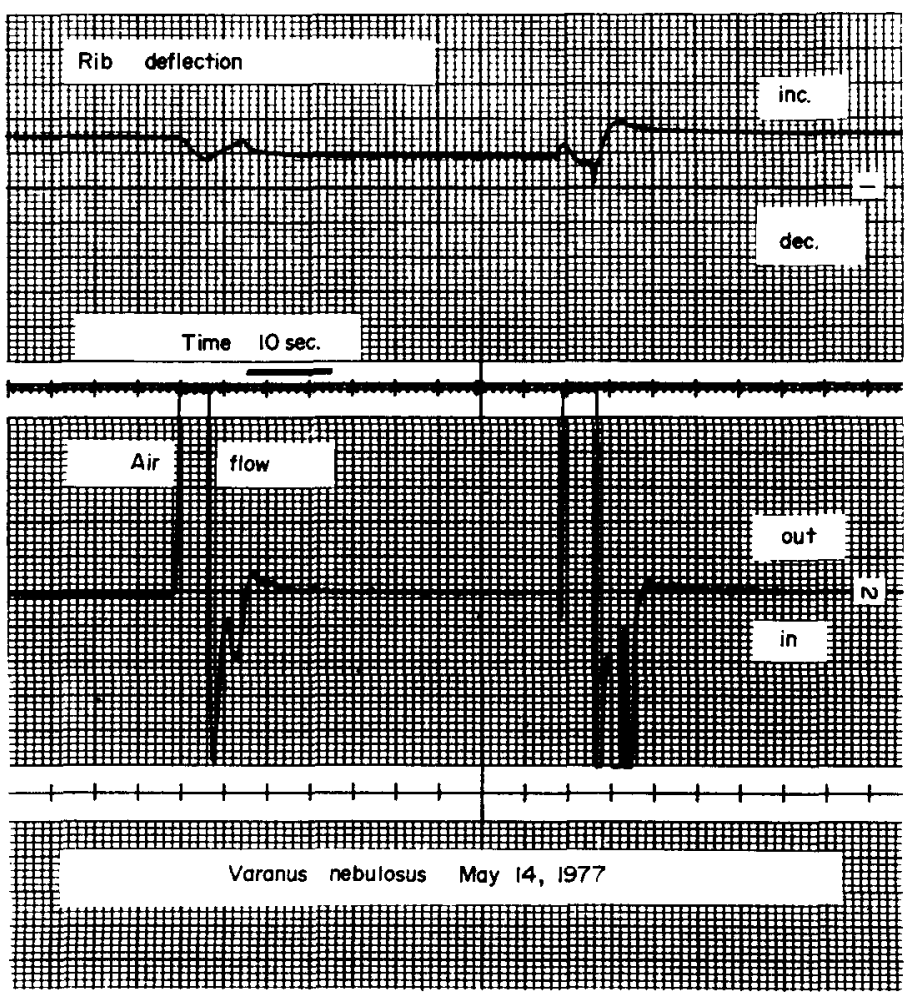

Fig. 3. Same animal (and amplifier settings) as in Fig. 2. Here the experimenter entered the room. exciting the animal and inducing it to inflate (note change in baseline of the rib deflection curve). The magnitude of tidal flow increased and a slight secondary exhalation is apparent. The diminished rib oscillations reflect a slight shift in the posture of the lizard. 
to be triphasic for three distinct reasons. These are (1) that they derived flow patterns from a limited number of indirect measurements of pressure or body movement, (2) that they used closed manometric techniques to monitor breathing, and (3) that the animals were physically restrained or hyperexcited for other reasons.

(1) The amount of gas passing via the nostrils presumably reflects shifts in the arrangement of the thoracic elements (and consequently of the impedance across them), changes of thoracic diameter, and the differences between intrapulmonary and ambient pressures. However, flow is modified by the condition of the glottal (and possibly of the narial) valves. A change in pulmonary pressure or impedance, or in thoracic diameter would only correspond to airflow if the glottis and nares were open (Fig. 2); partial restriction of these valves would have graded effects on the flow rate. Consequently the output of plethysmographs (Randall et al., 1944; Bennett, 1973; Rosenberg, 1973), records of intrapulmonary pressure (Charbonnel-Salle, 1883; Templeton, 1964), or of body wall excursions (Bert, 1869; Babak, 1914; Templeton \& Dawson, 1963) cannot immediately be used to predict flow, unless the configuration of the glottis is monitored simultaneously (as effected by Gans \& Clark, 1976).

The position of the lungs within the visceral cavity becomes important in this connection. Displacement of the postero-ventral aspect of the lung involves displacement of the remainder of the visceral tissues, which are elastic, non-homogeneous, and only loosely restrained with respect to each other. Consequently, they do not move as a uniform piston, but show relative displacements both during and after ventilatory muscular activity.

(2). Clark et al. (1978) have shown that the application of an externally imposed back-pressure may, in snakes, produce major intrapulmonary pressure fluctuations and indirectly modify the periods of glottal closure. This explains results such as those of Rosenberg (1973) in which a closed Kopfkappe with inadequate volume led to triphasic flow recordings, presumably because of delayed glottal closure. It also raises some questions as to the mechanisms by which the closure of the glottis is monitored. It appears that in the caiman (Gans \& Clark, 1976) opening is initiated via a burst of activity of the $M$. dilator and is maintained by its low level activity, while closing involves a sharp burst of activity in the glottal constrictors, with closure apparently maintained by the intrinsic elasticity of the glottal cartilages, possibly coupled with adhesion of the glottal lips. It seems likely that stretch receptors within the lung (Gatz et al., 1975; Milsom \& Jones, 1976; Fedde et al., 1977; Scheid et al., 1977) provide sensory feedback to the glottis, so that artificially high back-pressures might prove to be the proximate cause of abnormal glottal activity.

(3). Turtles and caimans, implanted with chronic EMG electrodes and left undisturbed for days, often breathe very shallowly and slowly, seemingly with minimal muscular activity. If they are disturbed, and particularly if they have been handled (and in some cases when food is offeren), they breathe much more deeply, and the pressure levels, particularly of exhala- tion, rise markedly (Fig. 3). Whenever the ventilation cycles of animals run into each other there may be a tendency for the glottis to remain open beyond the inhalatory period. As most reptiles appear to let their viscera droop when resting and consequently maintain a positive pulmonary pressure during apneusis, any delay in closure will induce a secondary exhalation. Forced distension of the buccal cavity may cause such an effect (Mitchell \& Morehouse, 1863) and already Bert (1869) (also François-Frank, 1909) had observed that the glottis sometimes remains open in excited animals.

The time required for airflow may have further advantages to the animal. As the rate of ventilation is increased, forcible displacement of ribs and viscera may have to be maintained until, or slightly beyond the instant that the glottis closes. When animals snorkel while swimming, the duration of ventilation is affected by the depth of water over the trunk, and presumably also by the excitatory state of the animal. Reptiles that are diving generally shift from a breathing sequence in which each ventilation is interrupted by a prolonged apneusis to one in which there is a short series of two or more ventilatory cycles before the next apneustic period (and dive). Presumably such animals flush out the respiratory dead-space and thus facilitate an increased length of apneusis and a more prolonged dive. There may be some selective advantage to breathing more rapidly in order to reduce the length of time that the animal remains exposed at the surface.

The importance of the apneustic period as an integral portion of the reptilian ventilatory rhythm must be stressed. Presumably it is not equivalent to the exceptional event described as apneusis in mammals (Sears, 1977), and discussions whether apneusis occurs during the inhalatory or the exhalatory phase of reptilian ventilation probably lack meaning. Gas is continuously exchanged from the pulmonary contents throughout the apneustic period (Lenfant et al., 1970). This sugggests that exhalation of this low $\mathrm{O}_{2}$-high $\mathrm{CO}_{2}$ gas must logically proceed before fresh air is aspirated. The relative length of the apneustic and ventilatory periods will reflect the metabolic rate, the ratio of tidal volume to ventilatory dead space, and such ecological factors as the cost a diving animal incurs for each trip to the surface. The latter is presumably refiected in the series of multiple breaths between apneustic periods seen in diving reptiles.

The external gas exchanger also serves secondary functions in permitting distension of the body and hissing as part of a threat display (Gans \& Maderson, 1973; Martin \& Huey, 1971). For instance, disturbed or excited crocodilians will engage in repeated inhalation-exhalation cycles and some species of crocodilians will even inhale air through the nostrils and exhale by forcing it through the posterior pharyngeal fold (Garrick \& Lang, 1977). Similar excitatory conditions may be reflected in the reports that turtles such as Emys orbicularis (Lüdicke, 1936) and Sauromalus (Salt, 1943; Templeton, 1964) tend to inflate their body by buccal pumping rather than by aspiration. Until such systems are analysed with a combined approach based on experiments involving simultaneous pressure records, electromyograms and flow measurements, discussion seems futile. 
As far as can be determined, all reports of triphasic ventilation involve one of the three experimental variants here described. Consequently, it appears that reptiles ordinarily ventilate with a purely biphasic flow pattern. departing from this only when they are highly excited or when utilizing airflow for the production of warning signals or in social communication.

Acknowledgements - We are grateful to Mr Keith Shaw for his careful work in designing and building the flowmeter, and to all those who loaned us animals for test. This work was supported by NSF DEB76 19289 to C. Gans.

\section{REFERENCES}

BABAK E. (1914) Über die Atembewegungen und ihre Regulation bei den Panzerechsen (Crocodiliern). Pfiügers Arch. ges. Physiol. 156, 572-601.

BENNETT A. F. (1973) Ventilation in two species of lizards during rest and activity. Comp. Biochem. Physiol. 46A, 653-671.

BERT P. (1869) Des mouvements respiratoires chez les batrachiens et les reptiles. J. Anat. Physiol. 6, 113-139.

BOELAERT R. (1941) Sur la physiologie de la respiration des lacertiens. Archs Int. Physiol. 51, 379-437.

Charbonnel-Salle L. (1883) Recherches anatomiques et physiologiques sur le méchanisme de la respiration chez les chéloniens. Annls Soc. natn. Zool. 15, 1-20.

Clark B. D., Gans C. \& Rosenberg H. I. (1978) Air flow in snake ventilation. Respir. Physiol. 32, 207-212.

Couvreur E. (1898) Nouvelles études sur la respiration des chéloniens. Annls Soc. linn. Lyon 45, 5-8.

Dubsuga. (1882) Über die Atembewegungen der gemeinen Schildkröte (Testudo europaea). Biol. Ztrbl. 2, 382.

FedDe M. R., Kuhlmann W. D. \& Scheid P. (1977) Intrapulmonary receptors in the tegu lizard: I. Sensitivity to $\mathrm{CO}_{2}$. Respir. Physiol. 29, 35-48.

Françols-Frank Ch.-E. (1909) Études critiques et expérimentales sur la méchanique respiratoire comparée des reptiles. II. Lacertiens fissilingues (Lèzard ocellé). Archs. Zool. exp. gén. IV. ser. 10, 547-615.

GaNs C. (1971) Strategy and sequence in the evolution of the external gas exchangers of ectothermal vertebrates. Forma Functio 3, 81-104.

Gans C. \& Hughes G. M. (1967) The mechanisms of lung ventilation in the tortoise, Testudo graeca Linné. J. exp. Biol. 47, 1-20.

Gans C. \& Maderson P. F. A. (1973) Sound producing mechanisms in Recent reptiles: Review and comments. Am. Zool. 13, 1195 1203.

Gans C. \& Clark B. (1976) Studies on ventilation of Caiman crocodilus (Crocodilia: Reptilia). Respir. Physiol. 26, 285-301.

GARRICK L. D. \& LANG J. W. (1977) Crocodilian signals and behaviors. Am. Zool. 17, 225-239.

Gatz R. N., Fedde M. R. \& Crawford E. C. JR (1975) Lizard lungs: $\mathrm{CO}_{2}$-sensitive receptors in Tupinambis nigropunctatus. Experientia 31, 455-456.

Gaunt A. S. \& Gans C. (1969) Mechanics of respiration in the snapping turtle, Chelydra serpentina (Linné). $J$. Morph. 128, 195-228.

Heinemann C. (1877) Ueber die Athembewegungen der Reptilien. Pfü̈gers Arch. ges. Physiol. 15, 430-432.

Hill M. \& Givens R. B. (1969) Air to ground thermal sensor. In Flying Models, pp. 20-22, 26, 39, 41-43, 50 . Rajl. Publ., Sparta, IL (384 March).

Hughes G. M. (1973) Comparative vertebrate ventilation and heterogeneity. In Comparative Physiology (Edited by
Bolis C.. Schmidt-Nielsen K. \& Maddrell S. H. P.). North Holland, Amsterdam.

Hughes G. M. (1974) Comparative Physiology of Vertebrate Respiration. Heinemann, London.

Jammes Y. \& Grimaud C. (1976) Ventilation, pulmonary and cutaneous gas exchange in the awake lizard Lacerta viridis. Comp. Biochem. Physiol. 55A. 279-285.

JoNGH H. J. de \& Gans C. (1969) On the mechanism of respiration in the bullfrog. Rana catesheiana: A reassessment. J. Morph. 127, 259-290.

KAHN R. H. (1902) Zur Lehre von der Athmung der Reptilien. Arch. Physiol. 26, 29-52.

Lenfant C., Johansen K., Petersen J. A. \& SchmidtNiELSEN K. (1970) Respiration in the freshwater turtle. Chelys fimbriata. Respir. Physiol. 8, 261-275.

LÜDICKE M. (1936) Über die Atmung von Emys orbicularis L. Zool Jb. 56, 83-106.

MarTin W. F. \& HuEY R. B. (1971) The function of the epiglottis in sound production (hissing) of Pituophis melanoleucus. Copeia 1971, 752-754.

MCCuTCheON F. H. (1943) The respiratory mechanism in turtles. Physiol. Zool. 16, 255-269.

MiLsom W. K. \& JONES D. R. (1976) Are reptilian pulmonary receptors mechano- or chemosensitive"? Nature 261. 327-328.

Mitchell S. W. \& Morehouse G. R. (1863) Researches upon the anatomy and physiology of respiration in the Chelonia. Smithson. Contr. Knowl. 159, 1-42.

Naifen K. H., Huggins S. E. \& Hoff H. E. (1970) The nature of the ventilatory period in crocodilian respiration. Respir. Physiol. 10, 338-348.

Randall W. C., Stullken D. E. \& Hiestand W. A. (1944) Respiration of reptiles as influenced by the composition of the inspired air. Copeia 1944, 136-144.

ROSENBERG H. I. (1973) Functional anatomy of pulmonary ventilation in the garter snake, Thamnophis elegans. $J$ Morph. 140, 171-184.

Rouch G. (1886) D'un nouveau méchanisme de la respiration chez les thalasso-chéloniens. Bull. Soc. zool. Fr 2, 461-470

SALT W. (1943) Lungs and inflation mechanism in Sauromalus obesus. Copeia 1943, 193.

Schneid P., Kuhlmann W. D. \& Fedde M. R. (1977) Intrapulmonary receptors in the tegu lizard: II. Functional characteristics and localization. Respir. Physiol. 29, $49-62$.

SEARS T. A. (1977) The respiratory motoneuron and apneusis. Fedn Proc. Fedn Am. Socs exp. Biol. 36. $2412-2420$

Servaty A. \& Peyraud C. (1960) La méchanique respiratoire chez les reptiles et sa régulation. Bull. Soc. Hist. nat. Toulouse $95,145-170$.

SifferT E. (1896) Über die Athmung der Reptilien und Vögel. Pflügers Arch. ges. Physiol. 64, 321-506.

TEMPLETON J. R. (1964) Cardiovascular responses during buccal and thoracic respiration in the lizard, Sauromalus obesus. Comp. Biochem. Physiol. 11, 31-43.

Templeton J. R. \& Dawson W. R. (1963) Respiration in the lizard Crotaphytus collaris. Physiol. Zool. 36 104-121.

Tenney S. M., Bartlett D.. Farber J. P. \& Remmers J. E. (1974) Mechanics of the respiratory cycle in the green turtle (Chelonia mydas). Respir. Physiol. 22, $361-36 \%$.

Vos H. J. (1936) Over ademhaling en reukzin bij reptielen en amphibiën. Ph.D. thesis, Rijks-universiteit, Groningen.

Willem V. \& BertRand M. (1936) La triphasisme respiratoire chez les lezards. Bull. Acad. $r$ Belg. $\mathrm{Cl}$. Sci. Ser. $522,134-155$.

Wood S. C., Glass M. L. \& Johansen K. (1977) Effects of temperature on respiration and acid-base balance in a monitor lizard. J. comp. Physiol. 116B, 287-296. 